\title{
AUSTERITY-DRIVEN LABOUR MARKET REFORMS IN SOUTHERN EUROPE: ERODING THE SECURITY OF LABOUR MARKET INSIDERS
}

\author{
Amilcar Moreira ${ }^{*}$ Ángel Alonso Domínguez ${ }^{* *}$, \\ Cátia Antunes ${ }^{* * *}$, Maria Karamessini ${ }^{* * * *}$, \\ Michele Raitano ${ }^{* * * *}$ and Miguel Glatzer ${ }^{* * * * *}$
}

\begin{abstract}
The sovereign debt crisis in the Eurozone and increased pressures for 'structural reform' have led to a period of intensive change in labour market policy in Southern Europe. Examining the cases of Greece, Portugal, Spain and Italy, this article focuses on the security oflabour market insiders, a key group in labour markets that is highly segmented. The security of labour market insiders is conceptualised as consisting of security in employment (protection against dismissals) and security in unemployment (protection against drops in income provided by unemployment insurance and assistance). Using changes in national laws, the article charts and compares labour market change along these two dimensions across these four Southern European countries. Because labour

* University of Lisbon, Institute of Social Sciences, Av. Professor Aníbal de Bettencourt, 9, 1600-189 LISBOA, Portugal; phone: 00351217804700 ; email: amilcar.moreira@ics.ulisboa.pt.

** University of Oviedo, Department of Sociology, Facultad de Economía y Empresa, Campus Universitario de El Cristo, s/n, 33006 Oviedo, Spain; phone: 0034 985182633; email: alonsodangel@ uniovi.es.

*** University of Lisbon, Institute of Social Sciences, Av. Professor Aníbal de Bettencourt, 9, 1600-189 LISBOA, Portugal; phone: 00351217804700 ; email: catia.joao@ics.ulisboa.pt.

**** Panteion University of Social and Political Sciences, Department of Social Policy, Central Administration Building, 1st Floor, Syngrou Avenue 136, Athens 17671, Greece; phone: 0030 2109201755; email: mkarames@ath.forthnet.gr.

***** Sapienza University of Rome, Department of Economics and Law, Via del Castro Laurenziano 9, 00161 ROMA, Italy; phone: 00390649766347 ; email: michele.raitano@uniroma1.it.

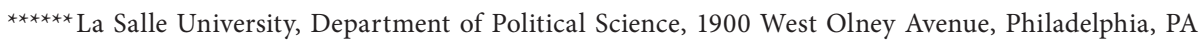
19141, USA; phone: 001 2159912851; email: glatzer@lasalle.

The authors acknowledge support from Project CABISE, CSO2012-33976; and from MINECO-13FCT-13-6137, both funded by the Spanish Ministry of Economy and Competitiveness. They would also like to thank Antonis Roumpakis, Pedro Pita Barros, Martin Rhodes, Theodoros Papadopoulos and two anonymous reviewers for their comments on earlier versions of the article.
\end{abstract}


market reform has not been restricted to Southern Europe, the article also compares these developments to broader changes in the countries of the Eurozone, using OECD and MISSOC data. Having demonstrated the degree to which the security of labour market insiders has diminished, the article concludes with an agenda for research on the policy dynamics of Southern European labour market reform in the wake of the financial crisis.

Keywords: employment security; Greece; Italy; labour market policy; labour market insiders; Portugal; Southern Europe; Spain; structural reform

\section{INTRODUCTION}

Following the eruption of a sovereign debt crisis in May 2010, the Greek government adopted an Economic Adjustment Programme in exchange for financial assistance provided by the European Commission, the European Central Bank and the IMF, commonly referred to as the Troika. This event marked the start of a period of intensive institutional change in the South of Europe. Under pressure from financial markets, international institutions and creditor countries within the European Union, countries in the South were prompted to introduce 'structural' reforms in the way they regulate their labour markets. ${ }^{1}$ As is evident from Table 1 , labour market reform activity was both intensive, involving numerous reforms over a very short period of time, and comprehensive, covering a wide range of areas, from employment protection legislation, wage-costs, internal flexibility and unemployment protection to collective bargaining and even active labour market policy.

Cross-national studies of the reforms introduced in this period are limited, and often focus on a broader set of cases. There is, of course, a growing base of countryspecific analysis of the reforms (see Baylos 2012; Bentolila and Jansen 2012; Martin Puela 2011; Valdés Dal-Ré 2011; Loy 2012; Raitano 2012; Papadimitriou 2012; Matsaganis 2013; ILO 2011; Karamessini 2012 2015; Koukiadaki and Kretsos 2012; Laskos and Tsakalotos 2013; ILO 2014; Ramalho 2013). However, there have been few attempts to look at these developments through a comparative lens, and they have important limitations. For example, most of the comparative studies focus more on the reforms introduced in reaction to the 'Great Recession' (see Tajgman et al. 2011; ECB 2012; Laulom et al. 2012) than on the most recent developments (OECD 2012; OECD 2013; Clauwaert and Schömann 2012). There are also few studies that focus specifically on developments in the South of Europe (see Meardi 2012). While these comparative studies usefully chart changes in policy, most do not assess the significance of this period of institutional reform. This article aims to fill this gap.

1 In addition to labour market reforms, Southern European countries have also been prompted to introduce reforms to the regulation of product markets, often through the opening up of regulated professions and services (e.g. Greece, Italy and Portugal). 
Amilcar Moreira, Ángel Alonso Domínguez, Cátia Antunes,

Maria Karamessini, Michele Raitano and Miguel Glatzer

Table 1. Labour market reforms in the South of Europe: 2010-2013

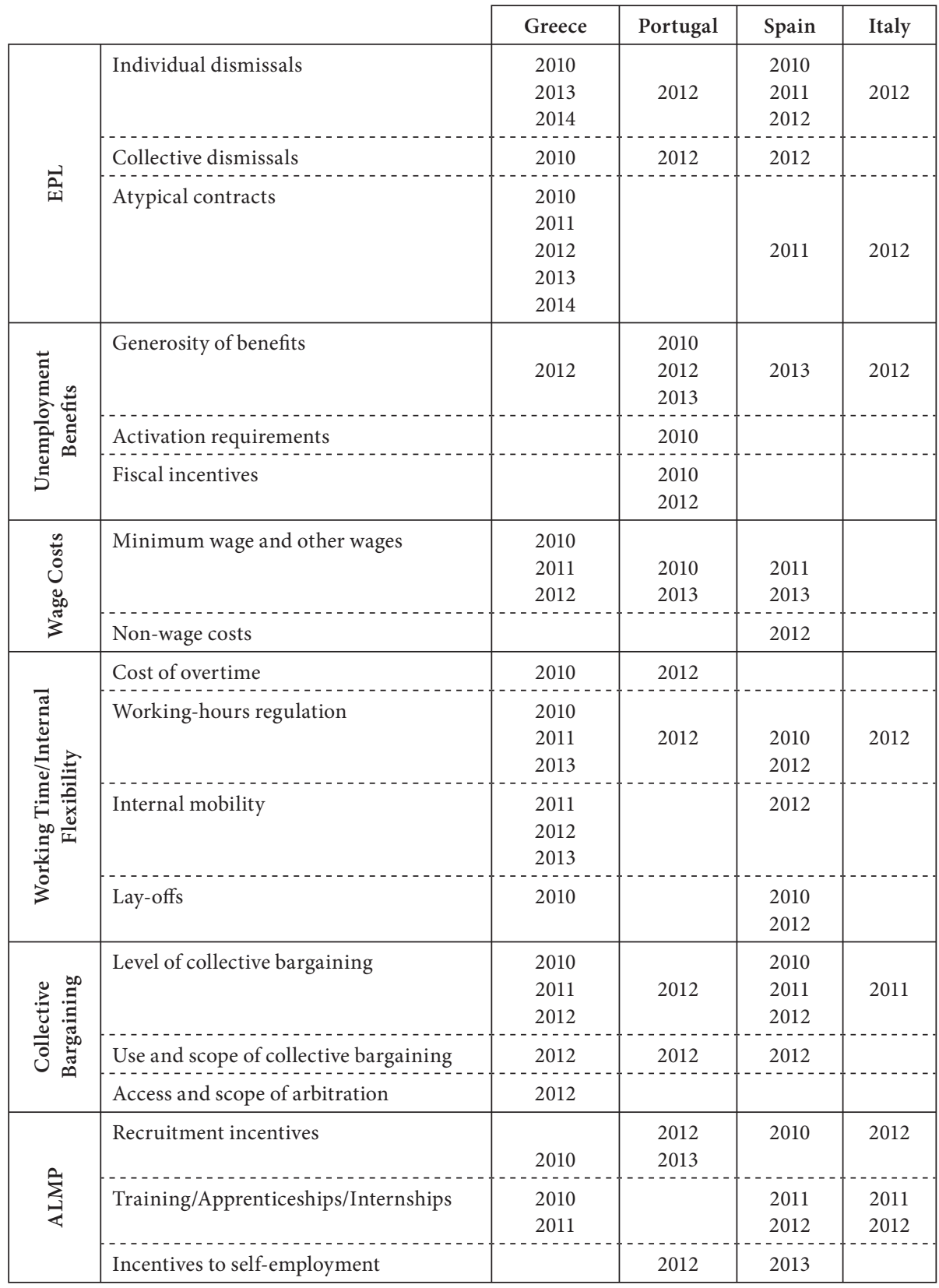

The significance of these reforms lies, first of all, in the way they reshape the model of labour market regulation in the South of Europe. As Muffels (2013: 218) points out, Southern European labour markets share an insider-oriented segmented labour 
market, characterised by high levels of employment protection for labour market insiders and a large number of atypical workers with very low levels of security. Karamessini (2008: 517) has argued that, historically, the stringent legislation against individual and collective dismissals was meant to protect male breadwinners. It reflects the legacy of authoritarian corporatism coupled with a family-oriented ideology, along with the social unrest and political change of the 1970s and 1980s. Although the four countries examined here followed different paths to flexibility from the 1980 s to the late 2000s, these invariably reinforced labour market segmentation by creating flexibility on the margins of the labour market while leaving those with permanent contracts largely protected. In line with this, this article assesses whether the reforms introduced between 2010 and 2013 affected the level of security enjoyed by labour market insiders in the South of Europe.

The article is structured as follows. Section 2 describes the policy changes introduced between 2010 and 2013. Section 3 assesses how these reforms changed the institutional setting that defines the security of labour market insiders in the South of Europe (Portugal, Spain, Italy and Greece). In order to better understand the significance of these reforms, this section also expands this exercise to include all countries in the Eurozone. Section 4 concludes by reflecting on how the results presented here can help shape future research on the impact of the crisis on the regulation of Southern European labour markets.

\section{RESEARCH METHODOLOGY AND DATA COLLECTION}

We used a two-pronged research method in this study. For Section 2, we reviewed national laws in Greece, Portugal, Spain and Italy to develop a list of changes to dismissal procedures, unemployment insurance and unemployment which we then grouped into distinct categories. For Sections 3 and 4, we used data from the OECD Benefits and Wages Indicators and MISSOC databases. We applied these data to modified versions of the indices of security in employment and security in unemployment developed by Papadopoulos (2005). Detailed information on the procedures is discussed in the relevant sections.

\section{REDEFINING SECURITY IN SOUTHERN EUROPEAN LABOUR MARKETS}

In this section we look at how reforms introduced during the period between 2010 and 2013 have redefined the security of labour market insiders in Southern Europe. Following Papadopoulos (2005: 20-22), we argue that the security of insiders depends on the degree to which labour market institutions offer protection against two fundamental risks: (1) the risk of (individual or collective) dismissal, i.e. security 
in employment; and (2) the risk of a sustained drop in income after the loss of employment, i.e. security in unemployment.

\subsection{SECURITY IN EMPLOYMENT}

As can be seen from Table 2, in recent years the level of employment security of regular workers in Southern Europe has been subject to significant change. Reforms introduced during this period were mainly concerned with lowering the cost to employers of dismissing regular workers (for an overview of reforms in Greece and Portugal under the Memoranda of Understanding, see also Petmesidou and Glatzer 2015). In Portugal, the new Labour Code, introduced in 2012, cut severance payments from 30 to 20 days per year and set a benefit ceiling of 12 times the employee's monthly wage or 240 times the minimum wage. ${ }^{2}$ In Greece (in 2013), private sector employees saw the notice period for individual dismissals reduced from a maximum of 24 to a maximum of 4 months and the level of severance pay cut from 2-24 months to 1-6 months (with prior notice) or 2-12 months (without prior notice). Severance pay for workers with more than 17 years of service was reduced from 24 to 12 months' wages (Karamessini 2015).

In Spain, in 2010, the Socialist government decided to expand the use of the Contrato de Fomento del Empleo, which was originally restricted to young people up to age 30, to those up to age 44 (Law 35/2010 of 17 September). This law provides lower compensation in the case of dismissal (33 days per year, compared to 45 for regular workers) and requires neither advance notice nor payment of interim wages. Later, in 2012, the Conservative government reduced severance pay to 20 days per year of tenure, with a maximum of 12 times the Spanish minimum monthly wage. ${ }^{3}$

Perhaps to soften the impact of these cuts in severance payments or perhaps in response to deteriorating economic conditions, Portugal (2013) and Italy (2012) introduced dismissal compensation funds (see Table 2). In Portugal (in 2013), the Conservative coalition introduced not one but two schemes ${ }^{4}$ - the Fundo de Compensação do Trabalho (FCT) and the Fundo de Garantia de Compensação do Trabalho (FGCT) - both funded by employers. FCT is an individualised fund that each employer must create for each employee, which capitalises on monthly contributions corresponding to 0.925 per cent of the worker's wage, and can be used by the employer to pay up to 50 per cent of the total severance pay. FGCT is a mutual fund which capitalises on monthly contributions corresponding to 0.075 per cent of one's wage, and can be used by the employee if s/he does not receive at least 50 per cent of the severance pay s/he is due.

\footnotetext{
2 This applied to both new and old contracts, although only to the time spent in the company since November 2011. Law no. 23/2012, Article 366, no.1.

$3 \quad$ Law $3 / 2012$ of 6 July.

4 Law $70 / 2013$.
} 
Besides reducing the cost of individual dismissal, countries in the South of Europe have sought to weaken the regime that protects regular workers against the risk of unfair dismissal. In Italy, following the 2012 labour market reform, firms with more than 15 employees are no longer automatically required to rehire employees in the event of unfair dismissal due to economic reasons. The duty of reinstatement was replaced by monetary sanctions that range from 6 to 24 months' wages depending on the length of employment (Clauwaert and Schömann 2013c: 7-9). In Spain, the Conservative government in 2012 reduced compensation for unfair dismissal for permanent contracts from 45 days of wages per year of tenure (with a ceiling of 42 months' wages) to 33 days per year of tenure (with a ceiling of 24 months). ${ }^{5}$

In Spain, consecutive governments have sought to broaden the ability of employers to dismiss employees for economic reasons. In 2010 new legislation allowed dismissals in the case of persistent drops in sales or revenues. ${ }^{6}$ In 2011, this regime was further expanded and dismissal permitted when it was part of a process of technological or organisational change aimed at improving the company's situation. In 2012, to reduce challenges to dismissals in the judicial system, the Spanish government introduced legislation that specifies that dismissals for economic reasons are only possible when the employer is able to demonstrate drops (including expected drops) in sales or revenues for three consecutive quarters. ${ }^{7}$

In Portugal, as part of the 2012 Labour Code, the government introduced profound changes with the goal of facilitating individual dismissals. This involved broadening the interpretation of fair dismissal in the case of unsuitability for the task, eliminating the regulation that protected senior workers in cases of dismissal, and eliminating the requirement that employers offer an alternative job in cases of unfair dismissal (Ramalho 2013: 9). However, in 2013, the Constitutional Court deemed these changes to the Labour Code unconstitutional. ${ }^{8}$ As a consequence, in 2014, the Portuguese government introduced legislation that defines the new criteria that employers must use when determining individual or collective dismissals. ${ }^{9}$ Under these new rules priority for dismissal is given to individuals with the lowest evaluations of performance, the lowest qualifications, the highest costs to the company, the lowest level of experience, and the fewest number of years in the company (in this order).

\footnotetext{
$5 \quad$ Law $3 / 2012$ of 6 July.

6 Law $35 / 2010$ of 17 September.

7 Law $3 / 2012$ of 6 July.

8 The elimination of the requirement that employers follow seniority when extinguishing a given position was deemed to open the way for the employer to discriminate among workers, which would violate the prohibition against unfair dismissal enshrined in Article 53 of the Constitution. The Court found that the elimination of the obligation to find a compatible position for a worker before his/her dismissal also violated the constitutional prohibition against unfair dismissal (see Constitutional Court Ruling no. 602/2013 in Diário da República (24/10/2013).

9 Law 27/2014.
} 
Amilcar Moreira, Ángel Alonso Domínguez, Cátia Antunes,

Maria Karamessini, Michele Raitano and Miguel Glatzer

Table 2. Changes to security in employment in Southern Europe 2010-2013

\begin{tabular}{|c|c|c|c|}
\hline $\begin{array}{l}\text { Policy } \\
\text { Area }\end{array}$ & Country & Year & Policy Changes \\
\hline \multicolumn{4}{|c|}{ Notification Procedure } \\
\hline & \multirow[t]{2}{*}{ Greece } & 2010 & $\begin{array}{l}\text { Notice period reduced from maximum of } 24 \text { to maximum of } 6 \\
\text { months }\end{array}$ \\
\hline & & 2013 & $\begin{array}{l}\text { Notice period reduced from maximum of } 6 \text { to maximum of } 4 \\
\text { months }\end{array}$ \\
\hline & Spain & 2011 & - $\quad$ Notice period reduced from 30 to 15 days \\
\hline \multicolumn{4}{|c|}{ Severance Pay } \\
\hline & \multirow[t]{2}{*}{ Greece } & 2010 & $\begin{array}{l}\text { - Severance pay cut from 2-24 months' wages to 1-6 months } \\
\text { (with prior notice) or 2-12 (without prior notice) }\end{array}$ \\
\hline & & 2013 & $\begin{array}{l}\text { - Severance pay for workers with more than } 17 \text { years of service } \\
\text { reduced from } 24 \text { to } 12 \text { months' wages. }\end{array}$ \\
\hline & Spain & 2012 & $\begin{array}{l}\text { - Simpler modalities for economic redundancies, compensated at } \\
20 \text { days per year }\end{array}$ \\
\hline & Portugal & $\begin{array}{l}2012 \\
2013\end{array}$ & $\begin{array}{l}\text { - Cut and introduction of a ceiling to severance pay } \\
\text { - Introduction of dismissal compensation fund }\end{array}$ \\
\hline & Italy & 2012 & - Introduction of a dismissal compensation fund \\
\hline \multicolumn{4}{|c|}{ Length of Trial Period } \\
\hline & Greece & 2010 & - Extension of the probation period from 2 to 12 months \\
\hline \multicolumn{4}{|c|}{ Unfair Dismissal: Definition, Compensation \& Reinstatement } \\
\hline & \multirow[t]{3}{*}{ Spain } & 2010 & $\begin{array}{l}\text { - Economic reasons become a justifiable reason for dismissal } \\
\text { - } \quad \text { Compensation for unfair dismissal reduced }\end{array}$ \\
\hline & & 2011 & $\begin{array}{l}\text { - Definition of fair dismissal was extended } \\
\text { - Obligation of reinstatement in the case of unfair dismissal is } \\
\text { replaced by monetary sanctions }\end{array}$ \\
\hline & & 2012 & $\begin{array}{l}\text { - Compensation for unfair dismissal is reduced from } 45 \text { days' } \\
\text { wages for every year worked (up to a ceiling of } 42 \text { months' } \\
\text { wages) to } 33 \text { days (with a ceiling of } 24 \text { months' wages) }\end{array}$ \\
\hline & Portugal & 2012 & - Factors that justify dismissals broadened \\
\hline & Italy & 2012 & $\begin{array}{l}\text { - Restrictions to the right to reinstatement in case of unfair } \\
\text { dismissal due to economic reasons }\end{array}$ \\
\hline & Greece & 2013 & - $\quad$ Protection against unfair dismissal reduced. \\
\hline \multicolumn{4}{|c|}{ Definition of Collective Dismissal } \\
\hline & Spain & 2012 & $\begin{array}{l}\text { - Collective dismissals are no longer dependent on authorisation } \\
\text { from public authorities } \\
\text { - Persistent or foreseen drops in sales/revenues (in three } \\
\text { consecutive quarters) become a reason for fair dismissal }\end{array}$ \\
\hline & Greece & 2010 & $\begin{array}{l}\text { - Increase in the minimum threshold for collective dismissals } \\
\text { from } 2-3 \% \text { to } 10 \% \text { of employees }\end{array}$ \\
\hline & Portugal & 2012 & - Seniority is no longer a criteria for determining dismissals \\
\hline
\end{tabular}


In addition to making individual dismissals easier, almost all countries have taken steps to facilitate collective dismissals (see Table 2). In Greece, in 2010, the minimum threshold for collective dismissals was increased from 2-3 per cent to 10 per cent (Karamessini, 2015). In Spain, since 2012, collective dismissals are no longer dependent on authorisation from national, regional or local authorities. Moreover, the period between notice and dismissals was reduced (OECD 2013: 96).

\subsection{SECURITY IN UNEMPLOYMENT}

As can be seen in Table 3, there have been substantial changes to the systems of unemployment protection in the South of Europe. The most common measure was a cut in the level of unemployment insurance benefits. Thus, in 2012, the Greek government decided to cut unemployment insurance benefits by 22 per cent (Matsaganis 2013: 20). In Spain (in 2012), the Conservative government decided that, after 6 months on benefit, unemployment insurance recipients would get only 50 per cent of their previous salary, not 60 per cent as was previously the case.

In Portugal, in 2010, the Socialist government cut the unemployment benefit from 65 per cent of gross earnings in the previous job, to the lower of 75 per cent of net earnings or 3 times the Social Support Index (SSI). In 2012, the Conservative government introduced further cuts in the level and duration of unemployment insurance benefits. The cap on unemployment insurance benefits was reduced from $€ 1.257$ to $€ 1048 .{ }^{10}$ In addition to this, the Government introduced a 10 per cent cut in benefits after 6 months. ${ }^{11}$ Still, the Government did approve a 10 per cent increase in benefits for unemployed couples (and lone parents) with children. ${ }^{12}$ However, later in 2013, the government decided to impose a 6 per cent tax levy on unemployment benefits above $€ 419 .^{13}$

Besides cutting the level of payments, some countries decided to slash the duration of unemployment benefits. This was the case in Portugal where, in 2012, the maximum duration of unemployment benefits was reduced from 900 to 540 days. ${ }^{14}$ It was also the case in Greece where, in 2011, the government introduced limits on the number of days a person could receive unemployment insurance over a period of 4 years, to 450 days in 2013 and 400 days in 2014 (Matsaganis 2013: 20).

\footnotetext{
$10 \quad$ Law no. 64/2012, Article 29, no. 1.

11 Law no. 64/2012, Article 28, no. 2.

12 Law no. 64/2012, Article 2, no. 1.

13 Law no. 51/2013, Article 10, no. 2.

14 See Law no. 220/2006, Article 37, no. 1 and Law no. 64/2012, Article 37, no. 1.
} 
Amilcar Moreira, Ángel Alonso Domínguez, Cátia Antunes,

Maria Karamessini, Michele Raitano and Miguel Glatzer

Table 3. Changes to security in unemployment in Southern Europe 2010-2013*

\begin{tabular}{|c|c|c|c|}
\hline $\begin{array}{l}\text { Policy } \\
\text { Area }\end{array}$ & Country & Year & Policy Changes \\
\hline \multicolumn{4}{|c|}{ Unemployment Insurance - Eligibility } \\
\hline & Portugal & 2012 & - Minimum contributory period reduced from 450 to 360 days \\
\hline & Italy & 2012 & $\begin{array}{l}\text { - New unemployment insurance scheme (ASpI), which extends } \\
\text { protection to apprentices and artists. } \\
\text { - Introduction of the Mini-ASpI, replacing the previous reduced } \\
\text { requirement unemployment benefit. } \\
\text { - Elimination of the 'Mobilità' allowance (for workers in medium } \\
\text { and large firms) }\end{array}$ \\
\hline & Greece & 2012 & - Unemployment insurance extended to self-employed \\
\hline \multicolumn{4}{|c|}{ Unemployment Insurance - Generosity of Unemployment Benefits } \\
\hline & Spain & 2012 & $\begin{array}{l}\text { - Cut in benefit after } 6 \text { months of receipt is strengthened (from } \\
60 \% \text { to } 50 \% \text { of previous salary) }\end{array}$ \\
\hline & \multirow[t]{3}{*}{ Portugal } & 2010 & $\begin{array}{l}\text { - Benefit cut from } 65 \% \text { of gross earnings in the previous job, to } \\
75 \% \text { of net earnings } \\
\text { - } \quad \text { Introduction of a } € 1257 \text { ceiling on benefits }\end{array}$ \\
\hline & & 2012 & $\begin{array}{l}\text { - } \quad \text { Benefit ceiling cut from } € 1257 \text { to } € 1048 \text { Euros } \\
\text { - } \quad \text { Benefit cut by } 10 \% \text { after } 6 \text { months }\end{array}$ \\
\hline & & 2013 & - $\quad$ UI Benefit cut by $6 \%$ (tax levy) \\
\hline & Greece & 2012 & - $\quad$ Flat-rate unemployment benefit reduced by $22 \%$ \\
\hline \multicolumn{4}{|c|}{ Unemployment Insurance - Duration of Unemployment Benefits } \\
\hline & Portugal & 2012 & $\begin{array}{l}\text { - Cuts in the duration of benefits - maximum duration reduced } \\
\text { from } 38 \text { to } 26 \text { months }\end{array}$ \\
\hline & Italy & 2012 & $\begin{array}{l}\text { - New unemployment insurance scheme (ASpI), extends duration } \\
\text { of payments. }\end{array}$ \\
\hline & Greece & 2012 & $\begin{array}{l}\text { - Limit to the number of days a person is entitled to receive benefits } \\
\text { over a period of } 4 \text { years ( } 450 \text { in } 2013,400 \text { from } 2014 \text { onwards). }\end{array}$ \\
\hline \multicolumn{4}{|c|}{ Unemployment Assistance } \\
\hline & Spain & 2011 & $\begin{array}{l}\text { - } 6 \text { month special allowance (PRODI) for people over } 45 \text { was } \\
\text { eliminated and replaced by an individual retraining programme } \\
\text { (PREPARA) }\end{array}$ \\
\hline & Italy & 2012 & $\begin{array}{l}\text { - New unemployment assistance scheme (Mini-ASpI) for } \\
\text { employees with reduced contributions. }\end{array}$ \\
\hline & \multirow[t]{2}{*}{ Portugal } & 2010 & - Tightening of means-test (less generous equivalence scale) \\
\hline & & 2012 & - $\quad$ Duration of benefits cut by half for recipients under 40 \\
\hline & \multirow[t]{3}{*}{ Greece } & 2012 & $\begin{array}{l}\text { - Annual income threshold that serves as a means-test increased } \\
\text { from } € 5,000 \text { to } € 12,000\end{array}$ \\
\hline & & 2013 & $\begin{array}{l}\text { - Annual income threshold that serves as a means-test reduced } \\
\text { from } € 12,000 \text { to } € 10,000 \\
\text { - Cap on public expenditure on unemployment assistance }\end{array}$ \\
\hline & & & $\begin{array}{l}\text { - Unemployed assistance extended to young long-term } \\
\text { unemployed }\end{array}$ \\
\hline
\end{tabular}

Note:

* This does not include the withdrawal of stimulus measures introduced as a response to the 'Great Recession'. 
In a context of rapid growth in unemployment, there were modest efforts to expand the coverage of unemployment insurance schemes. In Spain, Law 32/2010 established a voluntary contribution to unemployment benefit for the self-employed, even if, due to excessive requirements, fewer than $20 \%$ of requests were resolved favourably. ${ }^{15}$ In Greece (2012), unemployment insurance was extended to self-employed workers. However, due to stringent eligibility criteria, very few of the self-employed who found themselves out of business had access to benefits (Karamessini, 2015) ${ }^{16}$ In Portugal (in 2012), the mandatory contributory period to be eligible for unemployment insurance benefits was reduced from 450 to 360 days (in the last 730 days). ${ }^{17}$

Probably the most substantial effort to improve the coverage of unemployment insurance benefits in the South of Europe was the introduction, in Italy in 2012, of the Assicurazione Sociale per l'Impiego (ASpI) scheme, which replaced a rather broken web of individual schemes with a more unified system of unemployment protection that also encompassed apprentices, who were previously not covered. Under the new scheme, all employees who had started to work as an employee at least two years before becoming unemployed and who have worked at least 52 weeks since then are entitled to unemployment protection for a period of 12 months. The benefit amounts to 75 per cent of the previous wage, up to a threshold, which starts to decrease after 6 months of receipt (Raitano 2012).

While it attempts to expand the coverage of unemployment protection, the new system still contains important gaps in coverage. As it maintains the eligibility requirements of the ordinary unemployment benefit, the ASpI fails to protect some categories of workers - employees working for less than two years, or with an intermittent working history - who are particularly prevalent among the younger generations. Moreover, the new scheme does not create new guarantees for the self-employed and, in particular, for para-subordinate workers, i.e. continuous and project collaborators, whose designation as self-employed is often questionable (Raitano 2012).

It should also be noted that, starting in 2015, the 2012 reform abolished the mobility allowance. This was the most generous unemployment benefit in Italy because it lasted up to two years with an 80 per cent replacement rate. However, the mobility allowance was granted only to those working either in industrial firms with at least 16 employees or in service firms with at least 50 employees.

Although they are less relevant to the protection of labour market insiders, Southern European countries have also made important changes to the eligibility

15 Available at www.segsocial.es/Internet_1/Estadistica/Est/Otras_Prestaciones_de_la_Seguridad_ Social/ceseactividadRETA/ Ceseactividad2013/index.htm.

16 The unemployment insurance scheme is now open to self-employed workers whose annual personal income is below $€ 10,000$ (or with annual family income below $€ 10,000$, averaged over the two years prior to claiming) who have ceased their activity after January 2012, and have paid social contributions for at least 12 months in the last three years, and are not in debt to social security (Matsaganis 2013: 21).

17 Law no. 64/2012, Article 22, no. 1. 
and generosity of non-contributory unemployment benefits. In 2010, as part of an initial attempt to deal with the onset of the sovereign debt crisis, the Portuguese government introduced a series of welfare cuts which involved, among other things, the tightening of eligibility for assistance-based schemes, accomplished through the introduction of a less generous equivalence scale (Moreira et al. 2014: 247). ${ }^{18}$ Later, in 2012 , the Conservative coalition cut by half the duration of unemployment assistance for recipients under $40 .{ }^{19}$ In Spain (in 2011) the Socialist government decided to eliminate the 6 months special allowance (PRODI) that was previously available to people over 45 who had exhausted their unemployment insurance right. In its place, the government introduced PREPARA, an individual retraining programme which acts as a safety-net for unemployed persons who have exhausted all benefits and allowances. $^{20}$

In Italy, where there are no non-contributory unemployment benefits, in parallel to the introduction of the ASpI programme, the government introduced the MiniASPI scheme. It is paid to employees who do not fulfil ASpI requirements and replaces the previous reduced requirement unemployment benefit - traditionally, directed at seasonal workers or at those with very short working periods. Benefits are calculated using the same formula as in ASpI (the replacement rates are the same), but payments only last half of the previous worked weeks, with a maximum of six months. Under the scheme, entitlement to unemployment protection is possible if the individual has worked for the 13 weeks prior to the dismissal.

Possibly as a consequence of the complexity of the Greek political situation during this period, we find a number of contradictory developments regarding the final safety-net for unemployed workers. Thus, in 2012, the Greek authorities introduced a (small) reform, which involved raising the annual income threshold that serves as a means-test from $€ 5,000$ to $€ 12,000$, to broaden the coverage of the unemployment assistance scheme. However, this was followed by a decision to reduce the annual income threshold to $€ 10,000$ from January 2014, and to limit government expenditure on the scheme to $€ 35$ million, which in effect restricts the number of recipients to about 14,500. In another change, in 2013 the Greek government decided to expand the scheme to cover the young (and not just the old) long-term unemployed (Matsaganis 2013: 21).

18 The previous legislation used a fairly generous equivalence scale, which entitled each adult, up to two adults, to 100 per cent of the amount of the Social Pension and each adult, from the third, to 70 per cent of that amount. Each minor, up to two, was entitled to 50 per cent of the amount of the Social Pension and, from the third minor, received $60 \%$. The new Act adopts the OECD equivalence scale, in which the second adult in the household receives 70 per cent of the benefit of the head beneficiary, and each child receives 50 per cent (Moreira et al. 2014:247).

19 Decree 64/2012.

20 PREPARA replaces the Temporary Unemployment Protection and Insertion Programme (PRODI) (Royal Decree-Law 10/2009 of 13 August), launched in August 2009, whose goal was also to provide some income to workers who had exhausted their unemployment benefit or subsidies. 


\section{REDRAFTING THE BALANCE BETWEEN SECURITY IN EMPLOYMENT AND SECURITY IN UNEMPLOYMENT FOR REGULAR WORKERS IN THE SOUTH OF EUROPE}

The previous sections described the set of labour reforms introduced in the period between 2010 and 2013 in Southern Europe. In this section, we assess comparatively the impact of these reforms on the level of security enjoyed by labour market insiders in these countries. Following Papadopoulos (2005), we have put together two (composite) indexes that aim to measure the degree of security enjoyed by workers while in employment and while unemployed. ${ }^{21}$

\section{Box 1. Measuring Security in Employment}

By security in employment we mean the degree of protection regular workers enjoy against the risk of both individual and collective dismissal. This is measured by a composite indicator that uses OECD (2013) data to measure:

- The protection of regular workers against individual dismissal

- The protection of regular workers against collective dismissal

While we broadly reproduce the methodology adopted by the OECD (2013) to measure the level of employment protection, our indicator does not cover the regulation of temporary forms of employment.

Following the methodology adopted by the OECD (2013: 1-2), the sub-indicator that measures the level of protection of regular workers against individual dismissal is composed of nine items, covering:

- The length of the trial period

- The notification procedures that regulate dismissal processes, i.e. whether someone needs to be notified/give permission for the dismissal to occur, or length of the notice period

- The rules that define the compensation (severance pay) in case of dismissal

- The definition of fair/unfair dismissal; and the changes to the rules that define the compensation in case of unfair dismissal

The sub-indicator that measures the level of protection against additional collective dismissal is composed of four items, covering (2013: 1-2):

- The definition of collective dismissal

- Additional notification requirements in case of collective dismissal

- Additional delays involved before notice can start

- Other special costs to employers

$21 \quad$ While we follow the approach of Papadopoulos (2005), there are important differences in how the level of security of workers (both in employment and in unemployment) is measured. For instance, unlike Papadopoulos (2005: 15) our analysis of the level of security enjoyed by regular workers in employment does not include the regulation of temporary forms of employment. A more fundamental difference concerns the way security while unemployed is operationalised. Whereas, in Papadopoulos (2015: 15), the level of security in unemployment is measured by an (adjusted) indicator of expenditure on unemployment benefits and active labour market programmes, in this paper we look at the rules that determine the ease of access and generosity and duration of unemployment rates (see Box 2, Annex). 
Amilcar Moreira, Ángel Alonso Domínguez, Cátia Antunes,

Maria Karamessini, Michele Raitano and Miguel Glatzer

In line with the methodology adopted by the OECD (2013: 1-2), we have given a greater weight to the sub-indicator that measures the protection of regular workers against individual dismissal (0.75).

Building on OECD data, the first index measures the degree to which workers are protected against the risk of individual and collective dismissal (see Box 1). The second index uses comparative data (from MISSOC and the OECD) on labour market institutions to capture the degree to which unemployment insurance benefits protect workers against a sustained drop in income, which can be seen as a function of the ease of access to unemployment insurance and the level of income security while unemployed. The latter, in turn, is a product of the (gross) replacement rate secured by unemployment benefits and their maximum duration (see Box 2).

\section{Box 2. Measuring Security in Unemployment}

\footnotetext{
By security in unemployment, we mean the degree to which the system of unemployment protection protects regular workers against a sustained drop in income after the loss of employment. Using data on the rules that govern the entitlement and generosity of unemployment benefits (see OECD Benefits and Wages database ${ }^{22}$ and MISSOC). ${ }^{23}$ we created a composite index of security in unemployment. However, this is limited to unemployment insurance schemes.
}

This indicator covers two major dimensions of the protective ability of unemployment protection systems:

- The ease of access to unemployment insurance benefits

- The level of income security provided

In order to measure the ease of access to unemployment benefits, we created a sub-indicator that measures the number of social security contributions required to be entitled to unemployment insurance benefits. The underlying assumption is that the lower the number of contributions, the easier it will be for an individual to access the unemployment insurance benefits.

In order to make this indicator comparable across countries, we compare the ease of access for a 'typical' labour market insider, with the following characteristics.

- Age 35

- Employee

- Employment and Contributory career: In uninterrupted employment for two years, with insurance contributions paid for the same period

In addition to this, we have made a number of simplifying assumptions:

- In cases where there is only an employment requirement, we assume that the employment period is equal to the contribution period.

- In cases where the legislation imposes a minimum hours of work requirement, we assume the individual complies with this requirement.

In order to measure the ability of unemployment systems to protect against a drop in income, we calculate the gross replacement rate for an individual with the following characteristics:

- Age 35

- In two earner couple, with two children

\footnotetext{
22 Available at www.oecd.org/els/benefitsandwagesoecdindicators.htm

23 Available at www.missoc.org/MISSOC/INFORMATIONBASE/COMPARATIVETABLES/MISSOC DATABASE/ comparativeTableSearch.jsp
} 
- In unemployment for seven months

- Previous wage equal to 100 per cent of that of an average worker

- Not entitled to housing benefits or social assistance

As can be seen in Figure 1, in all four Southern European countries, the security of regular workers while in employment has been reduced. There are, however, some important differences between the four countries. The most obvious concerns the greater depth of the cuts in Portugal and Greece, compared with the more moderate changes introduced in Spain and Italy. In addition, in contrast with Italy and Spain, the cuts made in Portugal to the protection against individual dismissal clearly outweigh the cuts made to the protection against collective dismissals. It should be noted that our data underestimates the impact of the reforms in Greece, as it does not capture the effect of the measures to facilitate collective dismissals introduced in Greece in 2013 (see Table 1, Note b, Annex).

While confirming a reduction in the level of security enjoyed by labour market insiders while in unemployment, Figure 2 seems to suggest that the severity of the cuts made in this area are not as strong as in the field of employment. In other words, cuts in protection against dismissal appear to be greater than cuts to the system of unemployment benefits. To a certain degree, this reflects the fact that some of the most relevant reforms introduced during this period have not affected the security of regular workers as they were meant to expand unemployment protection to groups traditionally not covered by unemployment insurance, such as self-employed persons (Greece, Portugal and Spain) or apprentices (Italy) (see Section 2.2).

Figure 1. Security in employment in the South of Europe and Eurozone, 2010 and 2013

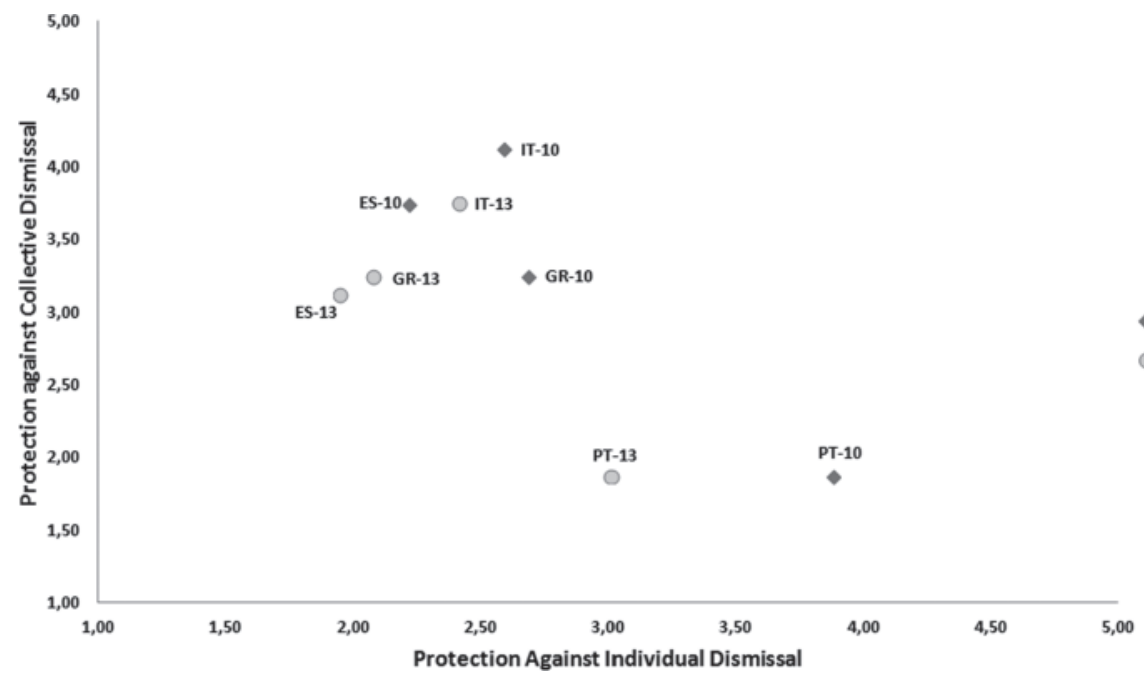


Amilcar Moreira, Ángel Alonso Domínguez, Cátia Antunes,

Maria Karamessini, Michele Raitano and Miguel Glatzer

Figure 2. Security in unemployment in the South of Europe and Eurozone, 2010 and 2013

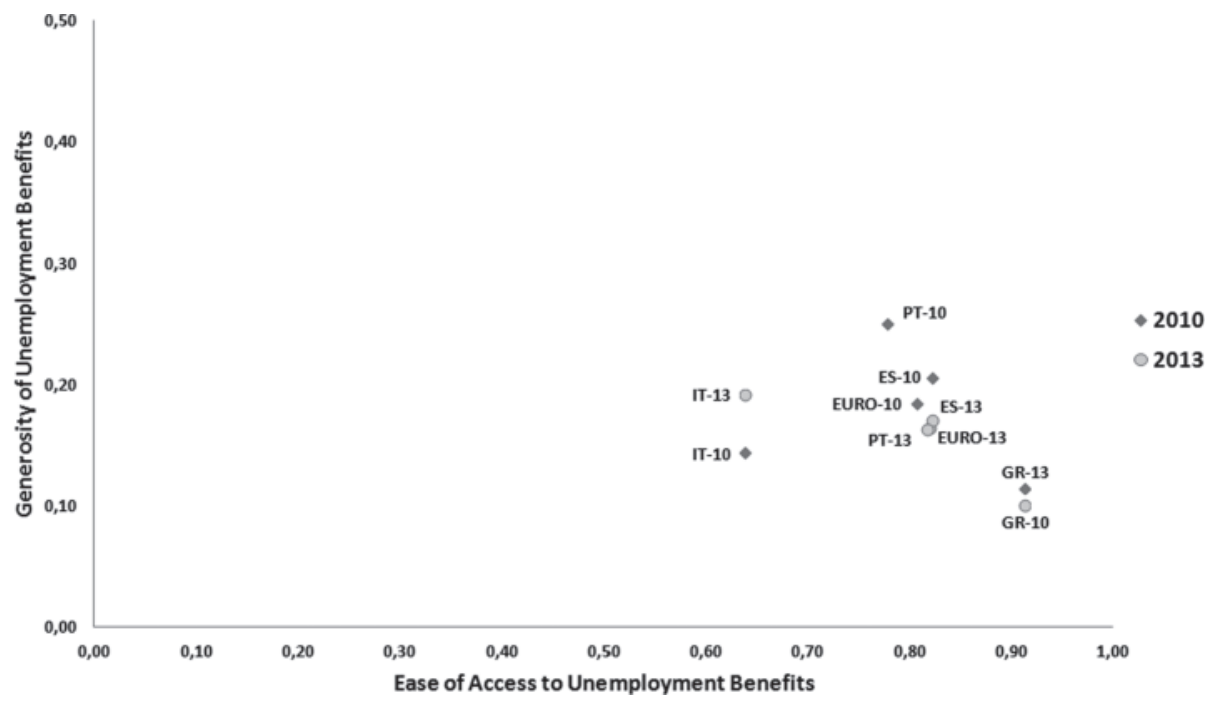

However, what seems to happening here is a statistical artefact that results from the decision to use gross replacement rates to measure the degree of income security offered to unemployed workers. ${ }^{24}$ As replacement rates are calculated for (idealtypical) individuals who received the average wage in the previous year, they are very vulnerable to how wages change over time. Depending on whether, and how, wages evolve, gross replacement rates can underestimate or overestimate the impact of welfare schemes on the actual living standards of individuals.

This limitation becomes obvious when we look at how the Greek case is reported here. As mentioned above, in 2012, the Greek government decided to cut by 22 per cent the minimum wage for unskilled workers (see Section 2.2), which is used as the benchmark for calculating the unemployment insurance rate (Karamessini 2012). However, as can be seen in Figure 2, the severity of this cut is not really reflected in the indicator that measures the changes in the income security of unemployed workers in Greece. While, to a certain degree, this can be explained by the fact that there were no changes to the duration of the benefit, it mainly reflects the fact that, between 2009 and 2012, the average worker wage decreased by 9.7 per cent - which means that the gross replacement rate underestimates the effect of the severe cut made to unemployment benefits on the living standards of the unemployed in this country.

24 There is a long tradition of using gross replacement rates to compare the ability of welfare programmes to substitute incomes from work (Esping-Andersen, 1990; Huber and Stephens 2001), even if these are not without limitations (see Martin, 1996; Scruggs 2007). 
Figure 3. Security in employment vs. security in unemployment in the South of Europe and the Eurozone 2010 and 2013

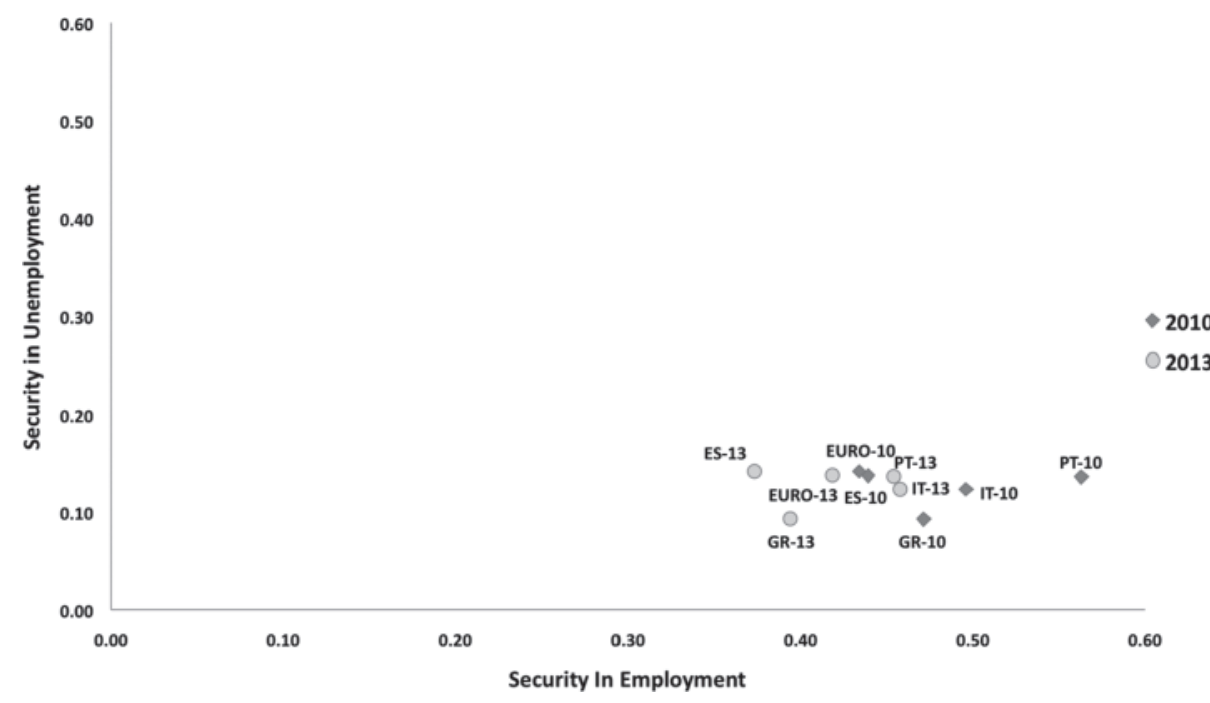

Despite these limitations, the data does confirm the impression that reforms introduced in Southern Europe in the period between 2010 and 2013 reduced the level of protection provided for regular workers who are unemployed. Still, as can be seen in Figure 2, access to unemployment benefits was not diminished. This suggests that reforms in this domain are less about retrenchment, and more about recalibration - i.e., reductions in the generosity of unemployment benefits to labour market insiders ran parallel with attempts to expand protection to previously unprotected groups (see Section 2.2).

As we have demonstrated, reforms introduced in the period between 2010 and 2013 have meant a significant reduction in the level of security enjoyed by labour market insiders in the South of Europe. As can be seen in Figure 3, when we put the developments in both areas in context we can conclude that, while there were important cuts in the level of security while in unemployment, the real significance of this period of reform lies in the substantive reduction of the level of protection enjoyed by labour market insiders in the South of Europe. The question that now remains is what these developments signify in terms of the process of European integration.

\subsection{SOUTHERN EUROPE IN CONTEXT}

Having shown that the reforms that were introduced between 2010 and 2013 have significantly reduced the level of protection for labour market insiders, in this section we expand our analysis to the other countries in the Eurozone (see Table 1, Annex). In order to make the depth of cuts more visible, we decided to plot the change in the level of protection given to regular workers relative to the lowest performing country in that year. 
Amilcar Moreira, Ángel Alonso Domínguez, Cátia Antunes,

Maria Karamessini, Michele Raitano and Miguel Glatzer

Figure 4. Security in employment: Difference to lowest performing country between 2010 and $2013^{*}$

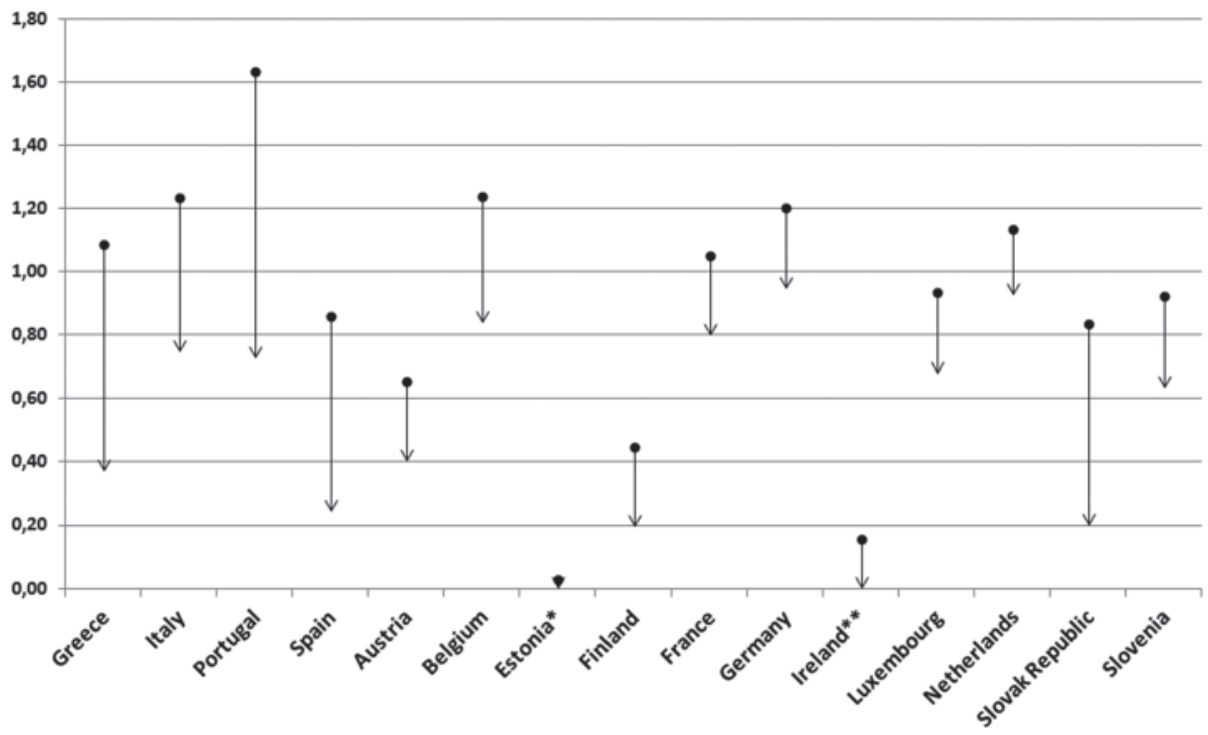

Note:

* Lowest performing country in 2010 is Estonia. Lowest performing country in 2013 is Ireland (see Table 1 , Annex).

Figure 5. Security in unemployment: Difference to lowest performing country between 2010 and $2013^{\star}$

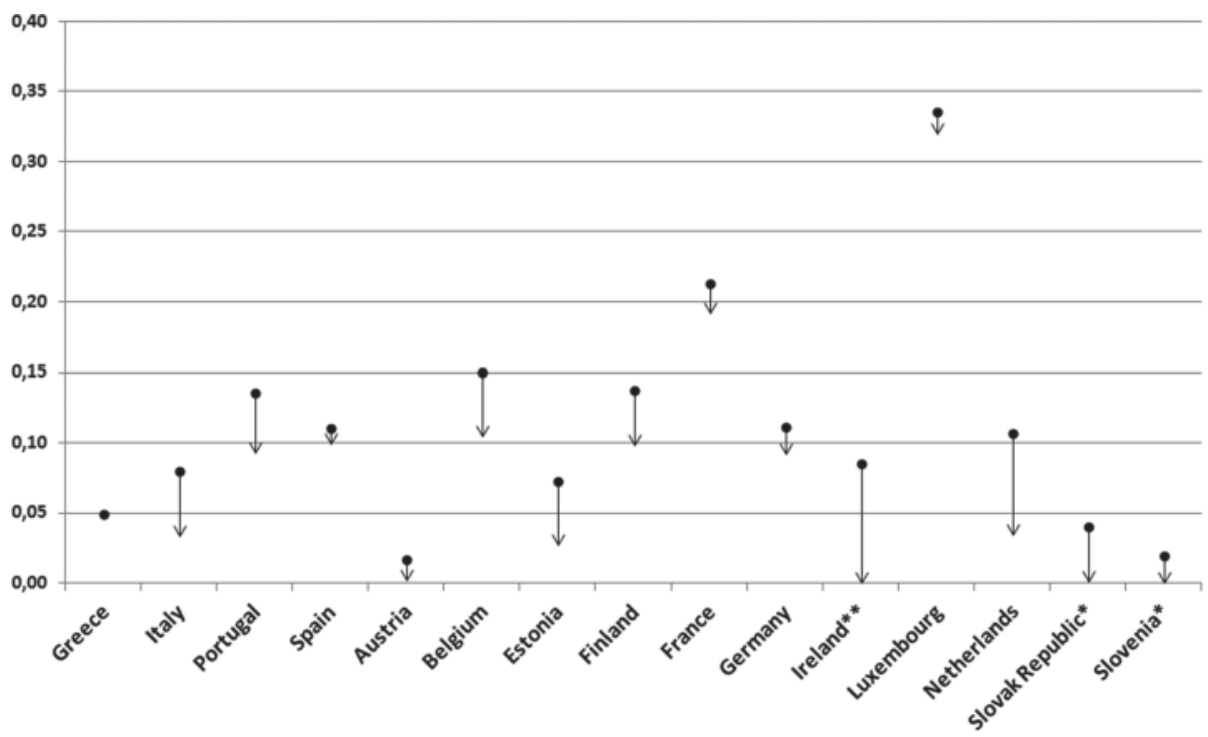

Notes:

* Lowest performing countries in 2010 are Slovak Republic/Slovenia.

** Lowest performing country in 2013 is Ireland (see Table 1, Annex). 
This exercise shows that Southern European countries were not the only countries to reduce the level of protection given to regular workers during this period. In fact, almost all countries in the Eurozone did so. As can be seen in Figures 4 and 5, cuts to the protection of regular workers in employment are (far) more substantial, with the deepest cuts introduced in Belgium and in the Slovak Republic, even though they were not subject to conditionality from international institutions.

Similarly, the Netherlands made the second-largest cuts in the level of protection given to regular workers while unemployed, even though it too was not subject to external conditionality. Among Eurozone countries, only Ireland made deeper cuts.

\section{CONCLUSION}

The sovereign crisis that hit Europe at the beginning of the decade prompted a wave of labour market reforms in the South of Europe. In this article, we showed that reforms introduced between 2010 and 2013 amounted to an important reduction in the level of security for labour market insiders both in employment and while unemployed. We then showed that this reduction was not exclusive to the South of Europe, which suggests an ongoing process of moving towards a model of labour market regulation characterised by lower levels of security in employment within the Eurozone.

While relevant, these findings must be put into perspective. First, the methodology used to measure the generosity of unemployment benefits tends to underestimate the effect of absolute cuts in the level of unemployment benefits in some countries (in particular Greece) on the income protection of labour market insiders when unemployed. Second, and most important, the above indicator cannot capture important gaps in the coverage of unemployment benefits in Southern Europe. With an unemployment rate of 26 per cent and a coverage rate by unemployment benefits of only 9 per cent of the unemployed in August 2014, Greece is the extreme case in this respect.

Last but not least, the developments reported here cover only half the story. For instance, our analysis does not cover changes made to the status of a special group of labour market insiders: public sector workers. In Greece, for example, employees in public enterprises saw the abolition of all clauses on tenure provided for by collective agreements and saw their labour contracts transformed into open-ended ones; while in public administration, labour reserve and mobility schemes were created in order to receive personnel made redundant, of whom a certain number have been dismissed (Karamessini, 2015).

Most importantly, the developments reported here do not take into account changes to the policies that regulate the security provided to labour market outsiders. Studying these changes is important in order to examine whether cuts in the security of labour market insiders are part of a de-segmentation strategy, or if they go handin-hand with a similar deterioration of employment conditions at the lower end of the labour market. 
Still, these results raise important questions regarding the process of institutional change currently underway in these four Southern European countries. As shown above (see Section 3), the pattern of change in employment protection legislation - clearly focused on retrenchment - is quite different from the recalibration that characterises change in the system of unemployment protection. Despite the introduction of cuts in the generosity and duration of benefits, there are also efforts to expand unemployment protection coverage to previously unprotected groups. This raises the issue of whether these efforts to expand unemployment protection coverage are (a) the product of compensation strategies (Glatzer, 1999; Pierson, 1994) adopted by policy-makers to make the introduction of cuts to unemployment protection more easily acceptable; (b) a reflection of a shift in the balance of power between labour market insiders, outsiders and employers, given that labour market institutions are an arena for the power dynamics between different social groups (Korpi 2001; Rueda 2005); or (c) simply, the result of a policy response to the rapid growth in unemployment in these countries to unprecedented levels.

The results in this paper also pose the question of the degree to which these developments are reflective of a new model of economic governance in Europe and an external policy agenda imposed through the conditionality associated with the provision of financial assistance, and the extent to which they reflect internal dynamics among local actors. Finally, and consequentially, these results raise the fundamental question of whether this period of reform signifies the dissolution of the Southern European model of labour market regulation, characterised by the protection of labour market insiders along with insecurity for outsiders.

\section{REFERENCES}

Ardy, B. And Begg, I. (2002) 'The European Employment Strategy: Policy Integration by the Back-Door?', Current Politics and Economics of Europe, 11(3), 187-204.

BAnK of Greece (2014) Annual Report by the Governor for 2013, Athens: Bank of Greece. BAylós, A. (2012) 'El sentido general de la reforma: la ruptura de los equilibrios organizativos y colectivos y la exaltación del poder privado del empresario', Revista de Derecho Social, 57, 9-18.

Bentolila, S. And Jansen, M. (2012) 'La reforma laboral de 2012: una primera evaluación', Apuntes Fedea Laboral, 14, 1-16.

Berton, F., Richiardi, M. And Sacchi, S. (2012) The Political Economy of Work Security and Flexibility. Italy in comparative perspective, Bristol, The Policy Press.

Clauwaert, S. And Schömann, I. (2012) 'The crisis and national labour law reforms: a mapping exercise', European Trade Union Institute, Working Paper 2012.04, $1-19$.

Clauwaert, S. And Schömann, I. (2013a) 'The crisis and national labour law reforms: a mapping exercise. Country report: Spain’, European Trade Union Institute. 
Claunaert, S. And Schömann, I. (2013b) 'The crisis and national labour law reforms: a mapping exercise. Country report: Portugal', European Trade Union Institute.

Clauwaert, S. And Schömann, I. (2013c) 'The crisis and national labour law reforms: a mapping exercise. Country report: Italy', European Trade Union Institute.

Claumaert, S. and Schömann, I. (2013d) 'The crisis and national labour law reforms: a mapping exercise. Country report: Greece', European Trade Union Institute.

ECB (2012) 'Euro area labour markets and the crisis', Occasional Paper Series, Frankfurt-am-Main: European Central Bank, 138, 1-120.

Eischorst, W., Feil, M. And Marx, P. (2010) 'Crisis, What Crisis? Patterns of Adaptation in European Labour Markets', IZA, Discussion Paper Series, 5045, $1-31$.

Esping-Andersen, G. (1990) The Three Worlds of Welfare Capitalism, Cambridge: Polity Press/Princeton, NJ: Princeton University Press.

Glatzer, M. (1999) 'Rigidity and Flexibility: Patterns of Labour Market Policy Change in Portugal and Spain, 1981-1996', South European Society and Politics, 4(3), 90-110.

GwiAzDA, A. (2011) 'The Europeanization of Flexicurity: the Lisbon Strategy's impact on employment policies in Italy and Poland', Journal of European Public Policy, 18(4), 546-565.

Heichel, S., PAPe, J. And Sommerer, T. (2005) 'Is there a convergence in convergence research? An overview of empirical studies on policy convergence', Journal of European Public Policy, 12(5), 817-840.

Huber, E. And Stephens, J. (2001) Development and Crisis of the Welfare State, Chicago, University of Chicago Press.

ILO (2011) Report on the High Level Mission to Greece (Athens, 19-23 September) Geneva, International Labour Organisation.

ILO (2014) Portugal. Tackling the jobs crisis in Portugal, Geneva, International Labour Organisation.

Karamessini, M. (2008) 'Still a distinctive Southern European model?', Industrial Relations Journal, 39(6), 510-531.

Karamessini, M. (2012) 'Sovereign debt crisis: an opportunity to complete the neoliberal project and dismantle the Greek employment model' in LEHNDORFF, S. (ed.) The triumph of failed ideas. European models of capitalism in crisis, Brussels: European Trade Union Institute.

Karamessini, M. (2015) 'The Greek Social Model: Towards a Deregulated Labour Market and Residual Social Protection' in Vaughan-Whitehead, D (ed.) The European Social Model in Crisis: Is Europe losing its soul? Geneva: ILO/ Cheltenham: Edward Elgar.

Korpi W. (2001) 'Contentious Institutions: An Augmented Rational-Action Analysis of the Origins and Path Dependency of Welfare State Institutions in the Western Countries', Rationality and Society, 13(2), 235-283. 
Koukiadaki, A. and Kretsos, L. (2012) 'Opening Pandora's Box: The Sovereign Debt Crisis and Labour Market Regulation in Greece', Industrial Law Journal, 41(3), 276-304.

Laskos, C. and Tsakalotos, E. (2013) Crucible of Resistance. Greece, the Eurozone and World Economic Crisis, London: Pluto Press.

Laulom, S., Mazuyer, E. Teissier, C., Triomphe, C.E. and Vielle, P. (2012) 'How has the crisis affected social legislation in Europe?' ETUI Policy Brief 2(2012), available at www.etui.org/Publications2/Policy-Briefs/European-EconomicEmployment-and-Social-Policy/How-has-the-crisis-affected-social-legislationin-Europe.

LeIbFried, S. (1993) 'Towards a European Welfare State? On integrating poverty regimes into the European Community' in Jones, C. (ed.) New Perspectives on the welfare state in Europa, London and New York: Routledge.

Loy, G. (2012) 'La reforme italienne: entre le malentendu de la flexibilité et la tentation du contrat unique', Revue du droit compare du travail et de la sécurité sociale, 2 , $38-49$.

Marí-Klose, P. and Moreno-Fuentes, F. (2013) 'The Southern European Welfare model in the post-industrial order', European Societies, 15(4), 475-92.

Martin Puela, E. (2011) 'Les réactions du droit du travail à la crise économique. Espagne: radiographie d'une réforme', Revue de Droit du Travail, 9 (September), 521-530.

Martin, J. (1996) 'Measures of replacement rates for the purposes of international comparisons: a note', OECD Economic Studies, 26, 99-116.

Matsaganis, M. (2011) 'The welfare state and the crisis: the case of Greece', Journal of European Social Policy, 21(5), 501-512.

Matsaganis, M. (2013) The Greek Crisis: Social Impact and Policy Responses, Berlin: Friedrich Ebert Stiftung.

Meardi, G. (2012) 'Labour market reforms in Italy and Spain: diversity and convergence', International Union Rights, 19(2), 3-5.

Moreira, A., Carolo, D. And Rui, N. (2014) 'From Gateway to Safety-Net. The dynamics of activation reforms in Portugal' in Lodemel, I. ANd Moreira, A., (eds.) Activation or Workfare? Governance and Neo-Liberal Convergence, Oxford/New York, NY: Oxford University Press.

Mosher, J. And Trubek, D. (2004) 'Alternative Approaches to Governance in the EU: EU Social Policy and the European Employment Strategy', Journal of Common Market Studies, 41(1), 63-88.

Muller, A. (2011) 'Employment protection legislation tested by the economic crisis: A global review of collective dismissals for economic reasons', Dialogue in Brief, 3 (September), 1-12, available at www.ilo.org/ifpdial/information-resources/ publications/WCMS_166754/lang--en/index.htm.

OECD (2012) 'Structural reforms in times of crisis', in Economic Policy Reforms 2012. Going for Growth, OECD Publishing. 
OECD (2013) 'Protecting Jobs, Enhancing Flexibility: A New Look at Employment Protection Legislation', in OECD Employment Outlook 2013, OECD Publishing.

PAPADIMITRIOU, C. (2012) 'Le droit du travail grec face à la crise: un passage dangereux vers une nouvelle physionomie juridique', Revue du droit comparé du travail et de la sécurité sociale, dossier thématique: 'Crise financière en Europe et droit social', 2, 6-17.

Papadopoulos, T. (2005) 'The Recommodification of European Labour: Theoretical and Empirical Explorations', European Research Institute, Working Paper Series, 3, 1-31.

Petmesidou, M. and Glatzer, M. (2015) 'The Crisis Imperative, Reform Dynamics and Rescaling in Greece and Portugal', European Journal of Social Security, this issue.

Pierson, P. (1994) Dismantling the Welfare State? Reagan, Thatcher and the Politics of Retrenchment, Cambridge: Cambridge University Press.

Raitano M. (2012) 'Ammortizzatori sociali: una riforma solo annunciata' in Lucchese M. And Ragozzino G. (eds.) Il lavoro in Italia. Dal precariato alla riforma Fornero, available at www.sbilanciamoci.info/ebook.

Ramalho, M.R. (2013) 'Portuguese labour law and industrial relations during the crisis', ILO Working Paper, 54, 1-28.

Rueda, D. (2005) 'Insider-Outsider Politics in Industrialized Democracies: The Challenge to Social Democratic Parties', American Political Science Review, 99, 61-74.

Scruggs, L. (2007) 'Welfare State Generosity Across Space and Time', in Clasen, J. And Siegel, N. (eds.) Investigating Welfare State Change, Cheltenham: Edward Elgar, 133-66.

Tajgman, D., Saget, C., Elkin, N. and Gravel, E. (2011) 'Rights at work in times of crisis: Trends at the country level in terms of compliance with international labour standards', ILO, Employment Working Paper, 101, available at www.ilo. org/employment/Whatwedo/Publications/working-papers/WCMS_167804/lang --en/index.htm.

Therborn, G. (2013) 'Where are the PIGS? Still a Southern European Welfare Regime?' European Societies, 15(4), 471-474.

VALDÉs DAL-RÉ, F. (2011) 'La ley de reforma del Mercado de trabajo: las singularidades de su objeto y los equivocos de sus objetivos', Relaciones laborales, 6, 1-7. 
Amilcar Moreira, Ángel Alonso Domínguez, Cátia Antunes,

Maria Karamessini, Michele Raitano and Miguel Glatzer

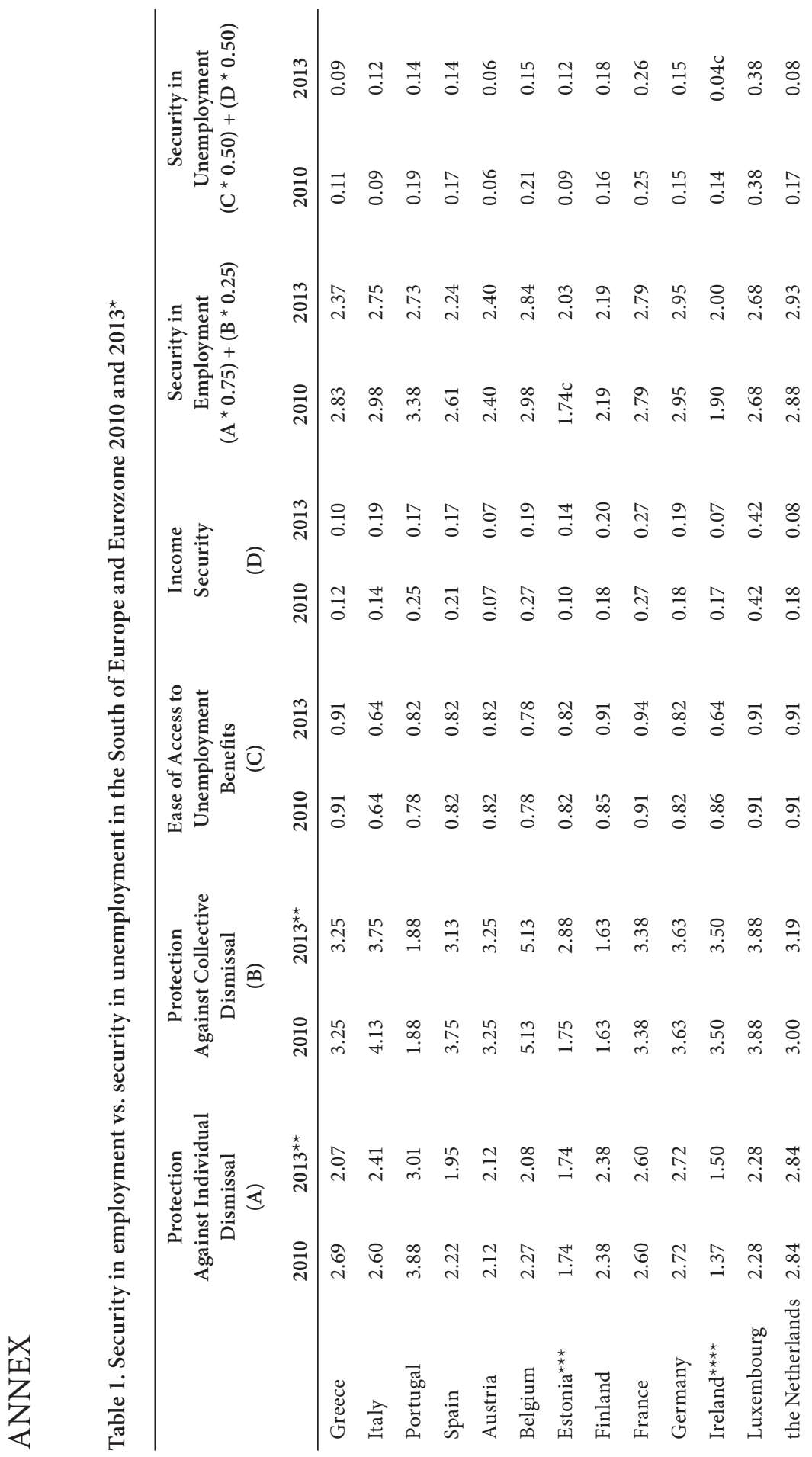




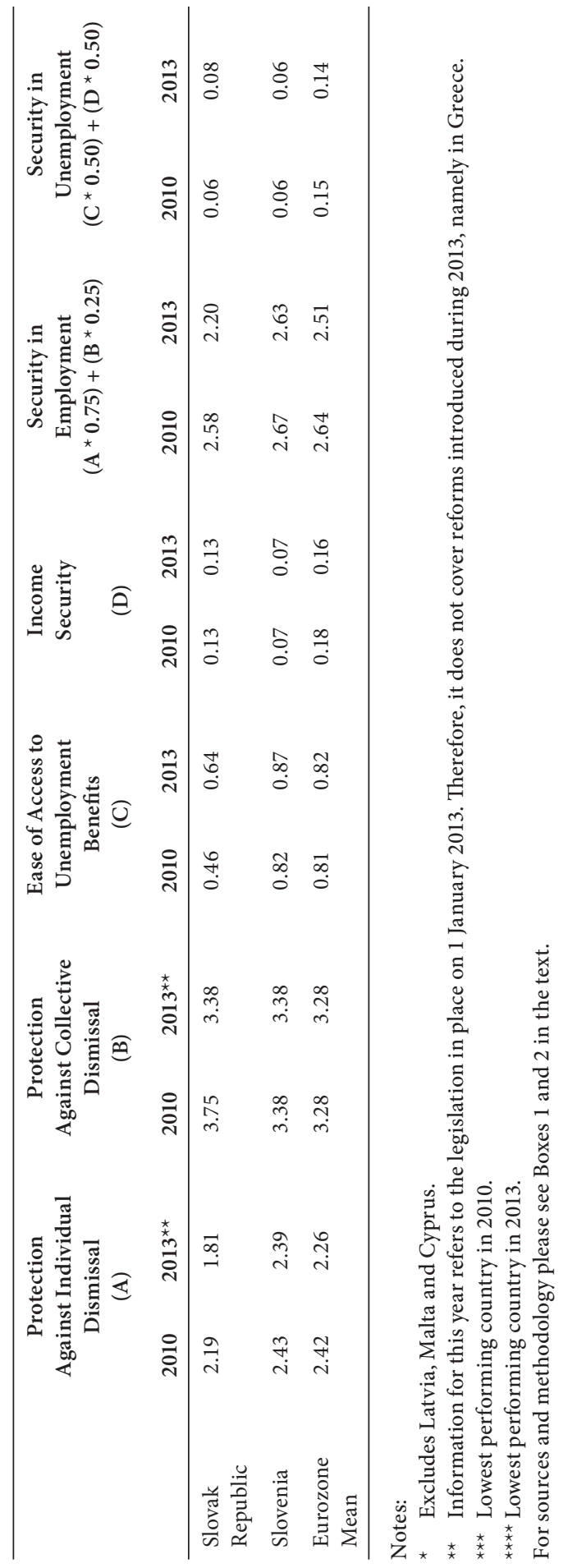

